$\longrightarrow$

MEDRESEARCH

www.medresearch.in

\section{Surgical Review: International Journal of Surgery Trauma and Orthopedics}

2020 Volume 6 Number 4 July-August

\title{
Clinicopathological study of carcinoma gallbladder and its management: a prospective study in a tertiary care hospital in Central India
}

\author{
Koshariya M. ${ }^{1}$, Suroshe T. ${ }^{2 *}$, Alex S. ${ }^{3}$, Rajput G. $^{4}, \mathrm{~K} \mathrm{M} \mathrm{G.}^{5}$, Vaidya K. $^{6}$, Shukla S. ${ }^{7}$, Patel B. ${ }^{8}$, \\ Shalini M. ${ }^{9}$, MC S. ${ }^{10}$ \\ DOI: https://doi.org/10.17511/ijoso.2020.i04.01
}

\begin{abstract}
${ }^{\mathbf{1}}$ Mahim Koshariya, Professor, ${ }^{2 *}$ Tushar Suroshe, Resident, ${ }^{3}$ Sharon Alex, Resident, ${ }^{4}$ Gaurav Rajput, Resident, ${ }^{5}$ Guka Priyan K M, Resident, ${ }^{6}$ Kunal Vaidya, Resident, ${ }^{7}$ Shikha Shukla, Resident, ${ }^{8}$ Badri Patel, Resident, ${ }^{9}$ Megha Shalini, Resident, ${ }^{10}$ Songra MC, Professor and Head; all authors are affiliated with the Department of Surgery, Gandhi Medical College and Associated Hamidia Hospital, Bhopal, Madhya Pradesh, India.
\end{abstract}

Background: Gallbladder cancer is a highly aggressive malignancy of the biliary system having the shortest median survival rate. Being aggressive biological nature and lack of sensitive screening test for early detection it has a poor prognosis. Aim: The purpose is to study the relative frequency of gallbladder cancer in reference to age, sex, etiological factors, clinical signs and symptoms in relation to the stages and the outcomes of different treatment modalities. Methods: This study is observational and conducted in the Department of General Surgery Gandhi Medical College and Aassociated Hamidia Hospital, Bhopal, Madhya Pradesh, during the period of 2017-2019. all patients who came themselves to OPD were evaluated further. Results: This study shows that majority of the patients were elderly females. Most of them presented with pain in the right hypochondrium found in 78 patients (78\%), nausea and vomiting in 36 patients (36\%), and jaundice in 30 patients (30\%). Tenderness in the right hypochondrium (85\%), anemia (78\%) followed by weight loss (68\%) were the three commonest signs. Conclusion: Gallbladder cancer is an aggressive malignancy of the biliary tract and has high case fatality with shortest median survival rates.

Keywords: Gallbladder cancer, Gallstones, Aggressive malignancy

Corresponding Author

Tushar Suroshe, Resident, Department of Surgery, Gandhi Medical College and Associated Hamidia Hospital, Bhopal, Madhya Pradesh, India. Email: drtushar103@gmail.com
How to Cite this Article

Koshariya M, Suroshe T, Alex S, Rajput G, Guka Priyan K M, Vaidya K, Shukla S, Patel B, Shalini M, Songra MC. Clinicopathological study of carcinoma gallbladder and its management: a prospective study in a tertiary care hospital in Central India. Surgical Rev Int J Surg Trauma Orthoped. 2020;6(4):223231.

Available From

https://surgical.medresearch.in/index.php/ijoso/artic le/view/197
To Browse

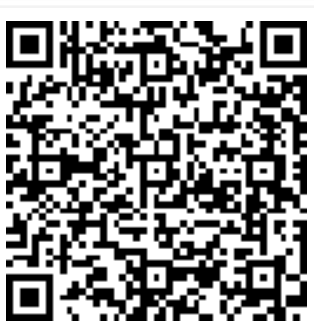




\section{Introduction}

Gallbladder carcinoma ranks sixth among all malignancies of the alimentary canal, having an incidence of 2.5 cases per 100,000 population in the united states [1]. Also, it's the most lethal malignancy of the biliary tract having the shortest median survival [2]. This poor prognosis is due to aggressive biological nature and lack of sensitive screening tests for early diagnosis results in diagnosis at an advanced stage. There is a robust association between gallstones and gallbladder malignancy, with gallstones detected approximately in $80 \%$ of cases [1]. Despite the availability of various diagnostic tests, gallbladder malignancy is generally recognized while doing the laparotomy presuming the diagnosis of benign pathology of the gallbladder. In 1-2 \% of patients, the diagnosis is made incidentally while undergoing operations for cholelithiasis during surgical exploration [2]. However, in India, the advanced disease is discovered in most of the patients in USG done for upper abdominal symptoms. Other risk factors for gallbladder cancer are porcelain gallbladder [2]. Solitary gallbladder polyp $>10 \mathrm{~mm}$ in patients older than 60 years of age [3]. Due to the abnormal pancreatico-biliary duct junction (APBDJ), there is reflex and stasis of the pancreatic juice into the gallbladder which results in chronic cholecystitis with intestinal metaplasia and subsequently leads to well-differentiated adenocarcinoma [4]. Chronic biliary infection with Salmonella enterica serovar Typhi [5]. Dysplasia and adenomas are the epithelial lesions involved in carcinogenesis. Dysplasia further progresses to carcinoma in situ (CIS) and subsequently becomes developed into invasive cancer. Over $80 \%$ of invasive gallbladder cancers present areas adjacent to the CIS and epithelial dysplasia [6]. High incidence of India and Native American Indians [7]. Indian ethnicity found to be an independent risk factor for developing gallbladder carcinoma in patients with gallbladder polyps in a study conducted on 137655 patients [7]. Gallbladder carcinoma is asymptomatic in initial curable stages and 3/4th of patients found to have an incurable disease when diagnosed; in remaining patients, it is found incidentally during interventions for calculus disease. It is found that reported 5-year survival rates of $<5 \%$ is the results of surgical experience with patient untreated and the undertreated [8].

\section{Material and Methods}

This was an observational study conducted in the Department of General Surgery Hamidia Hospital Bhopal, Madhya Pradesh, India after taking written informed consent. History and clinical data were obtained from patient and medical records. Complete blood picture, liver function test, coagulation profile, random blood sugar, renal function test, CEA has done in all patients. In radiological examination X-ray chest, USG abdomen, CECT abdomen done in all (Figures 1 and 2), and MRI with MRCP done in selected patients. USG guided FNAC / biopsy done in all patients for histopathological diagnosis. Biopsy proven cases managed according to the stage of the disease. Patients who found inoperable after investigations sent for chemoradiotherapy. The clinicopathological characteristic of all patients was analyzed including sex, age, symptoms, previous history of gallstone disease, physical findings, liver function test, results of ultrasound and computed tomography, stage of the disease, type of surgery performed, histopathological type.
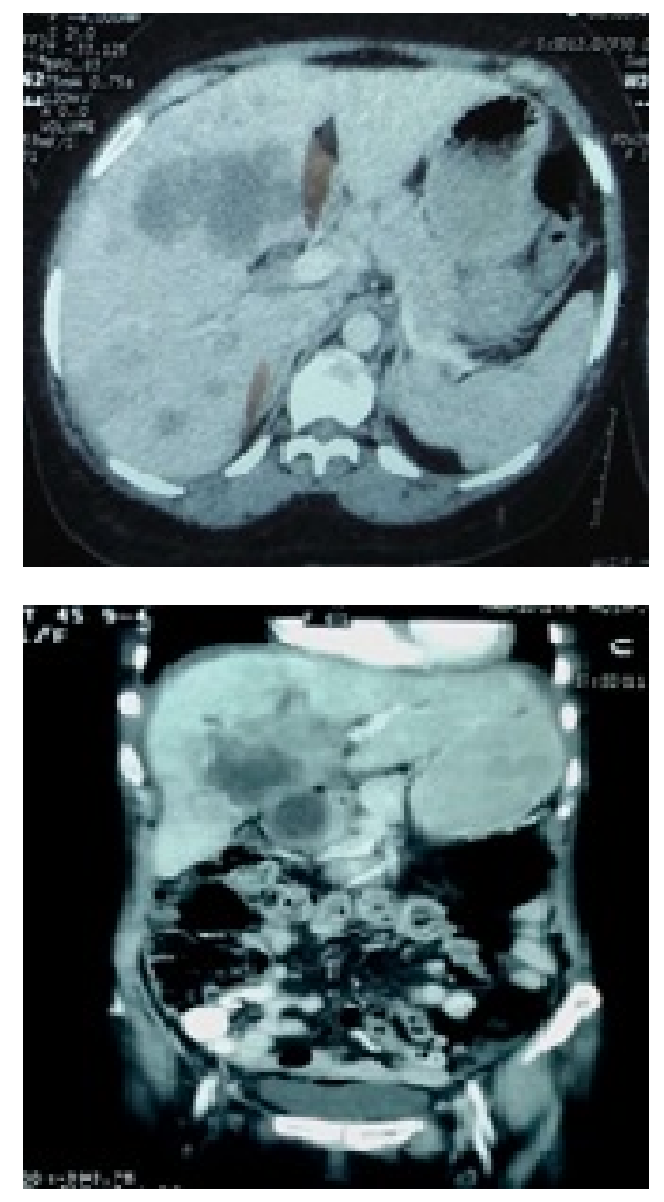

Fig-1: CECT abdomen showing the Gallbladder mass infiltrating liver bed with enlarged hepatico-duodenal Iymph nodes. 

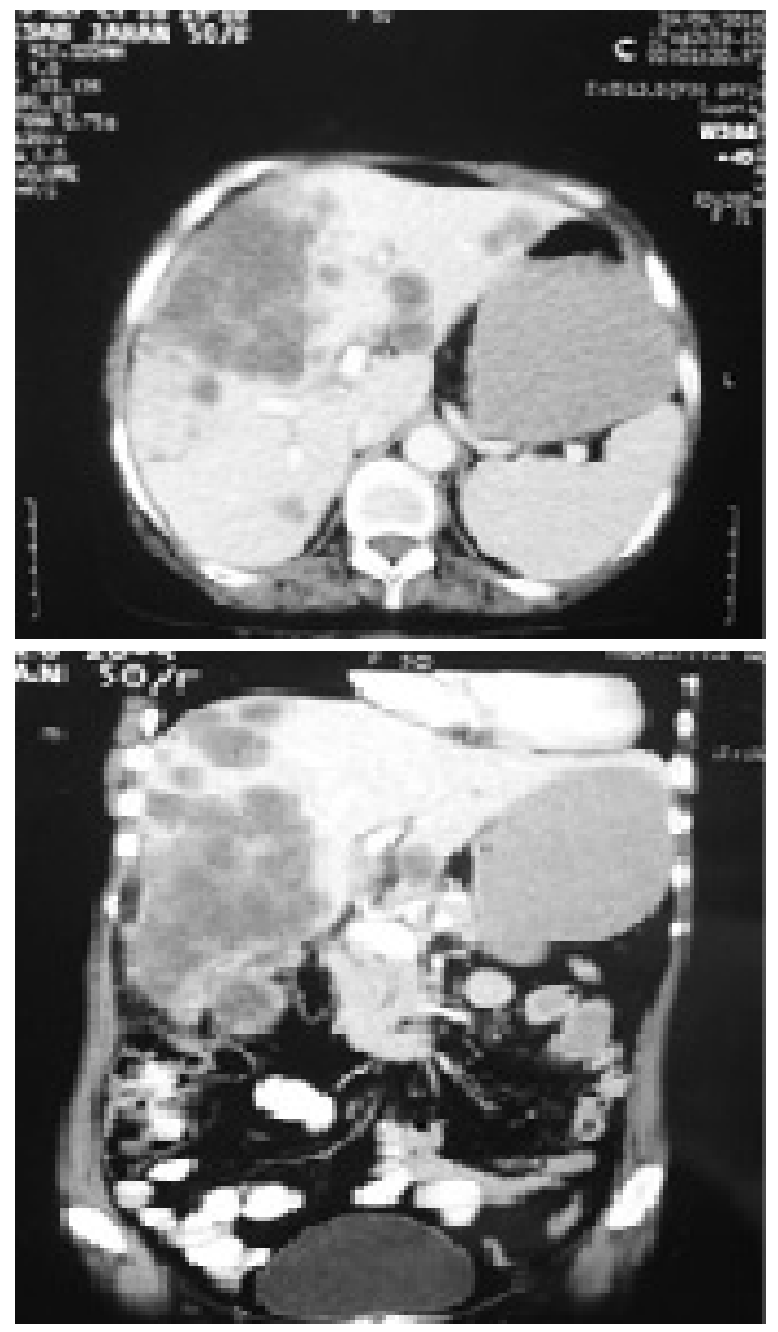

Fig-2: CECT abdomen showing mass completely involving gallbladder with multiple liver secondaries.

Treatment- The treatment modality given based on the stage of the disease at the time of diagnosis (Table 1). The only effective curative treatment is by surgical resection. Due to delayed presentation, only $10-30 \%$ of patients have resectable disease.

Table-1: Stage wise management of gallbladder cancer.

\begin{tabular}{|l|l|l|}
\hline Sr. & \multicolumn{1}{|c|}{$\begin{array}{c}\text { Surgical management of } \\
\text { gallbladder carcinoma }\end{array}$} & \multicolumn{1}{|c|}{ Recommendation } \\
\hline 1 & $\begin{array}{l}\text { Tis- (confined to mucosa) and T1a } \\
\text { (lamina propria) }\end{array}$ & Simple cholecystectomy \\
\hline 2 & T1b (invading the muscular layer) & Radical cholecystectomy \\
\hline 3 & $\begin{array}{l}\text { T2 tumors (invading the } \\
\text { perimuscular connective tissue }\end{array}$ & Radical enbloc resection along \\
\hline 4 & $\begin{array}{l}\text { T3 tumors (invading the serosa/liver } \\
\text { / adjacent organ) }\end{array}$ & Radical resection \\
\hline
\end{tabular}

\begin{tabular}{|l|l|l|}
\hline 5 & $\begin{array}{l}\text { T4 tumors (involving portal vein / hepatic artery/ }>2 \\
\text { extrahepatic organs) }\end{array}$ & $\begin{array}{l}\text { Chemo } \\
\text { radiotherapy }\end{array}$ \\
\hline
\end{tabular}

\section{Results}

The age of presentation varies between 35 to 80 years, the highest incidence found in the 5th and 6 th decade of life. Table 2 shows the results, the incidence of carcinoma of the gallbladder was $74 \%$ in female and $26 \%$ In males. It shows the highest incidence in females than in males with female to male ratio being $2.84: 1$.

Table-2: Age distribution.

\begin{tabular}{|l|l|l|l|l|}
\hline \multirow{2}{*}{ Age } & \multicolumn{2}{|c|}{ Number Patients } & \multirow{2}{*}{ Total $(\mathbf{n = 1 0 0})$} & $\%$ \\
\cline { 2 - 3 } & Male & Female & & \\
\hline Up to 40 & 4 & 16 & 20 & 20 \\
\hline $41-50$ & 7 & 21 & 28 & 28 \\
\hline $51-60$ & 9 & 25 & 34 & 34 \\
\hline 61 and above & 6 & 12 & 18 & 18 \\
\hline All ages & 26 & 74 & 100 & 100 \\
\hline
\end{tabular}

In this study most common presenting symptom was a pain in the right hypochondrium present in 78 patients $(78 \%)$, Jaundice was found in 30 patients (30\%). Nausea and vomiting felt by the 36 patients $(36 \%)$, loss of appetite (anorexia) found in 28 patients $(28 \%)$. The palpable lump was found in 30 patients $(30 \%)$ while the loss of weight and itching were in 14 patients (14\%). 10 patients (10\%) have a fever, 8 patients ( $8 \%$ ) presented with abdominal distension, and constipation and heartburn in $4 \%$ (Table 3).

Table-3: Clinical presentations $(\mathbf{n}=100)$

\begin{tabular}{|l|l|l|}
\hline \multicolumn{1}{|c|}{ Clinical Presentation\# } & Number of Patients & Percentage (\%) \\
\hline Pain in right hypochondrium & 78 & 78 \\
\hline Jaundice & 60 & 60 \\
\hline Nausea and vomiting & 36 & 36 \\
\hline Anorexia & 28 & 28 \\
\hline Lump & 30 & 30 \\
\hline Weight loss & 14 & 14 \\
\hline Fever & 10 & 10 \\
\hline Abdominal distension & 8 & 8 \\
\hline Itching & 14 & 14 \\
\hline Constipation & 8 & 8 \\
\hline Heartburn & 4 & 4 \\
\hline
\end{tabular}

(\# Same patient presents with multiple symptoms)

From 100 patients of gallbladder cancer 85 patients $(85 \%)$ have tenderness in right hypochondrium, 78 patients $(78 \%)$ were anemic, 68 patients $(68 \%)$ have weight loss, 30 patients $(30 \%)$ have palpable GB, 15 patients ( $15 \%$ ) have hepatomegaly, 13 
Patient (13\%) have ascites and only 1 patient (1\%) have splenomegaly (Table 4).

\section{Table-4: Physical findings of patients}

\begin{tabular}{|l|l|l|}
\hline \multicolumn{1}{|c|}{ Signs } & Number of Patients & Percentage \% \\
\hline Tenderness in right hypochondrium & 85 & 85 \\
\hline Weight loss & 68 & 68 \\
\hline Anemia & 78 & 78 \\
\hline Palpable gallbladder & 30 & 30 \\
\hline Jaundice & 30 & 30 \\
\hline Palpable liver & 15 & 15 \\
\hline Ascites & 13 & 13 \\
\hline Splenomegaly & 2 & 2 \\
\hline
\end{tabular}

Table-5: Distribution according to biochemical Investigation ( $\mathbf{n}=\mathbf{1 0 0})$.

\begin{tabular}{|l|l|l|}
\hline \multicolumn{1}{|c|}{ Investigation } & \multicolumn{1}{|c|}{$\begin{array}{c}\text { No of } \\
\text { Patients }\end{array}$} & \multicolumn{1}{|c|}{$\begin{array}{c}\text { Percentage } \\
(\%)\end{array}$} \\
\hline $\begin{array}{l}\text { Increased serum alanine } \\
\text { aminotransferase }\end{array}$ & 76 & 76 \\
\hline Elevated serum Alkaline phosphatase & 46 & 46 \\
\hline Prolonged prothrombin time & 35 & 35 \\
\hline Elevated serum bilirubin & 30 & 30 \\
\hline Low Haemoglobin level & 75 & 75 \\
\hline
\end{tabular}

This study gallstone is seen in 74 patients (74\%) in USG among which multiple stones were found in $73 \%$ of patients (73) and a single stone was in $27 \%$ patients (27). Soft tissue mass was found in 70 patients $(70 \%)$, most of them were originated from the fundal region of the gall bladder. 56 patients $(56 \%)$ presented with liver metastasis, dilated biliary channels were noted in 28 patients (28\%) ascites was found in 13 patients (13\%). Biliary sludge and soft tissue mass in gall bladder bed were detected both in USG and CECT in 10 patients $(10 \%)$, Lymphadenopathy detected by CECT in 10 patients (10\%) (Figure 3 ).

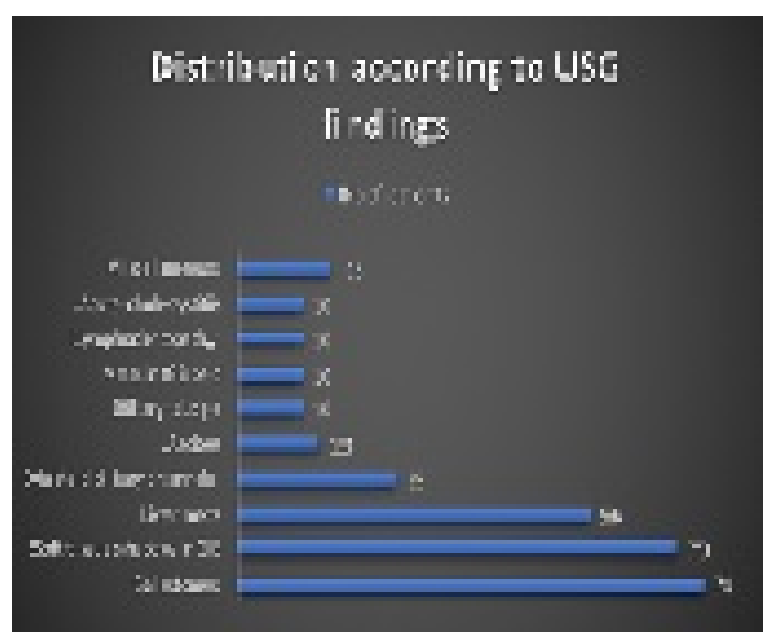

Fig-3: Graph showing patient distribution according to the USG findings. In the present study majority of patients were presented to us in advanced stage (Figure 4).

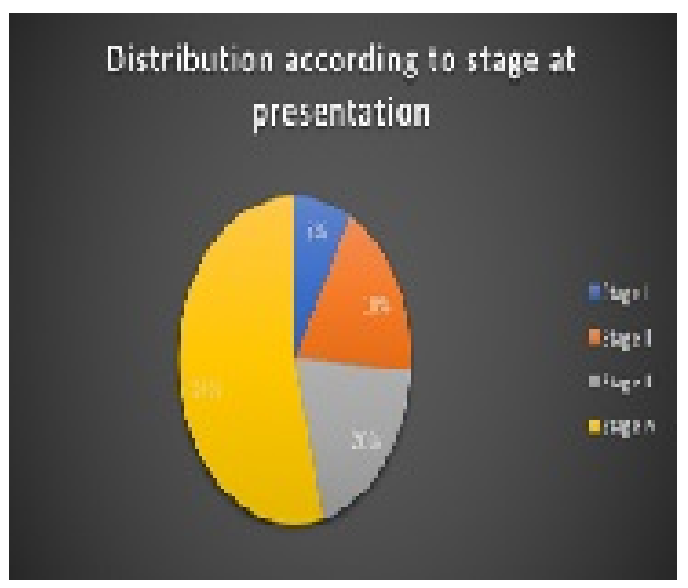

Fig-4: Pie chart showing patient's distribution according to the stage at presentation.

In this study 72 patients (72 \%) presented with features of inoperable diseases like ascites, Jaundice, multiple liver metastases and referred to chemoradiotherapy department. Presuming the patient is having benign pathology, it was found to have papillary carcinoma on histopathological examination in 2 Laparoscopic cholecystectomy patient (2\%) and adenocarcinoma in 1 open cholecystectomy patient (1\%), Extended open radical cholecystectomy was performed in 15 patients $(15 \%)$, Extended Laparoscopic cholecystectomy was done in 1 patient (1\%), Extended open radical cholecystectomy with rouxen-y hepaticojejunostomy done in 3 patients (3\%), 6 patients planned for a diagnostic laparoscopy (6\%) was found irresectable diseases and then only tissue sampling for histopathology was done (Figure $5,6,7,8,9)$.

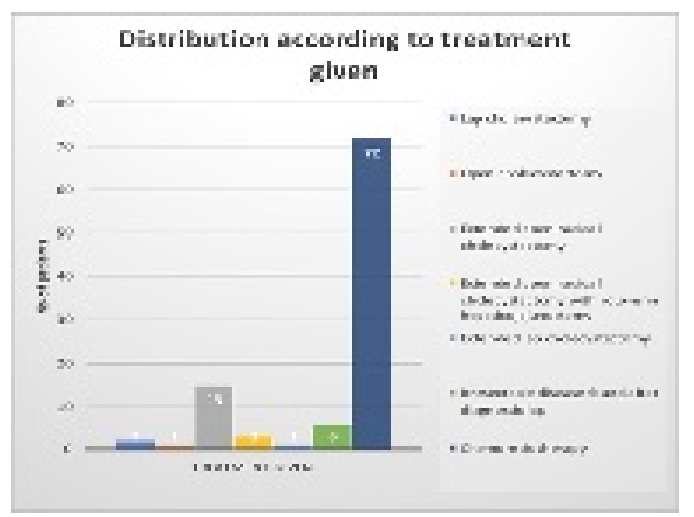

Fig-5: Histogram showing the patient's distribution according to the treatment given. 

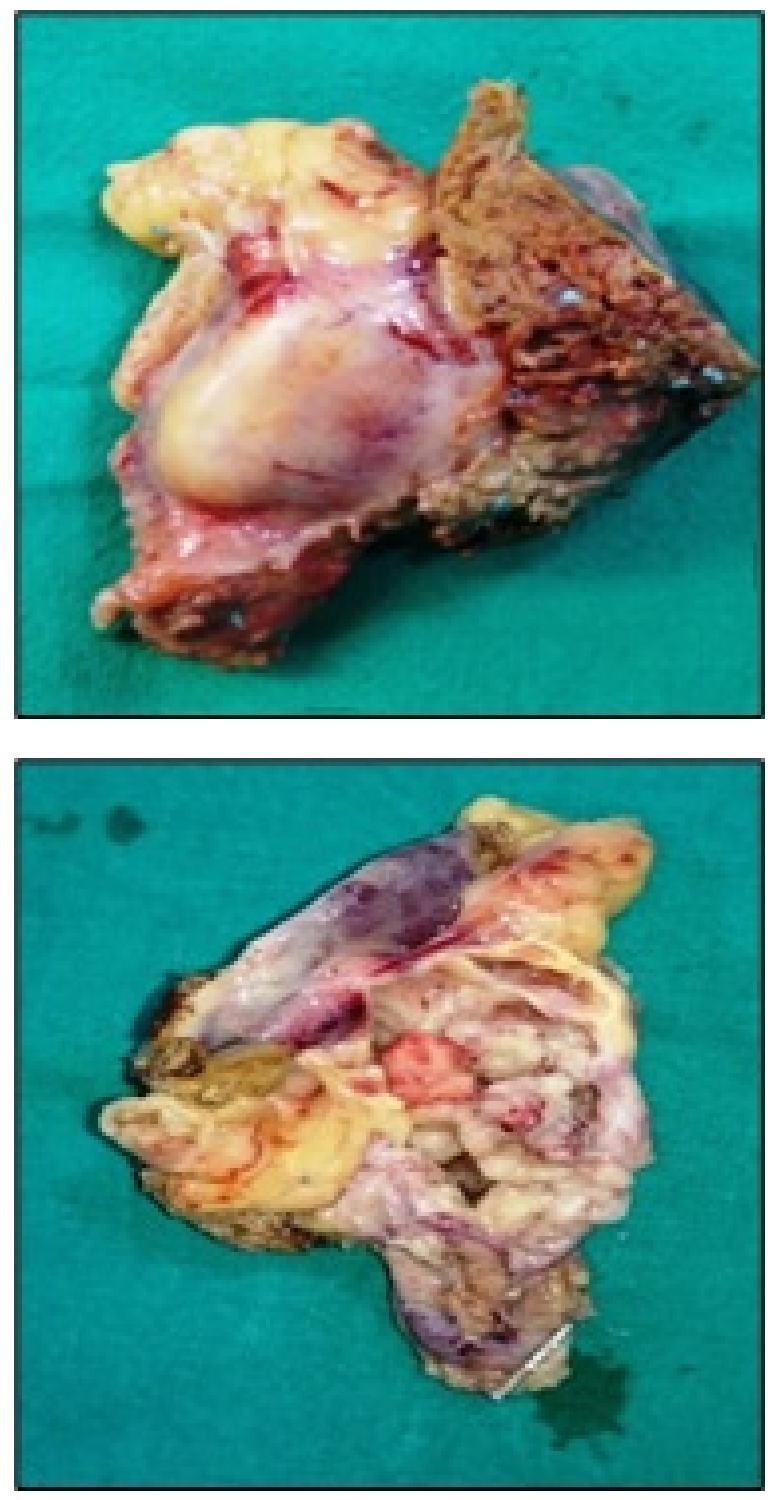

Fig-6: Showing laparoscopic extended cholecystectomy specimen of Gallbladder with growth within the lumen of GB incidentally found to have papillary CAGB on histopathology.

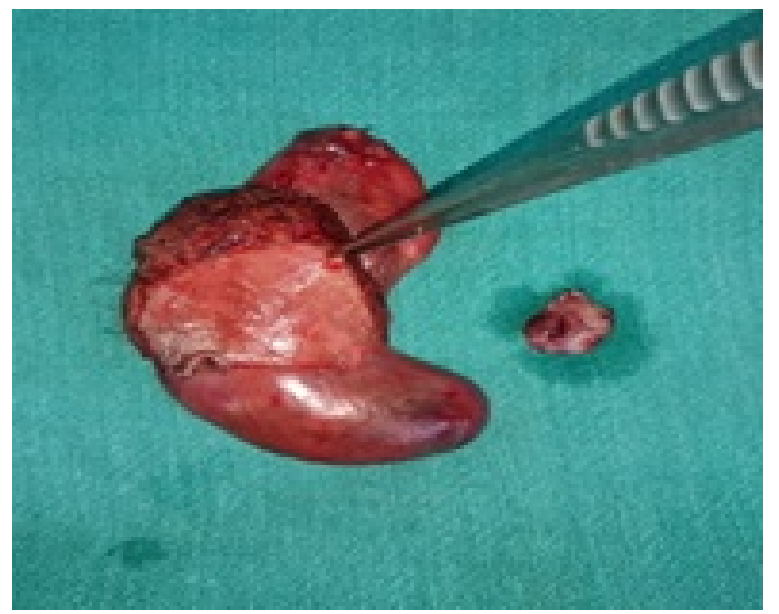

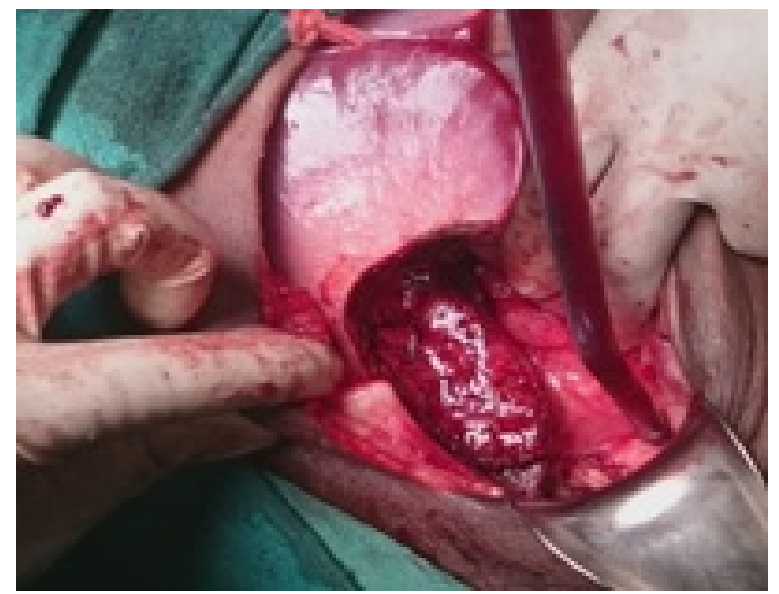

Fig-7: Showing resected specimen of gallbladder along with wedge resection of liver including segment IV.
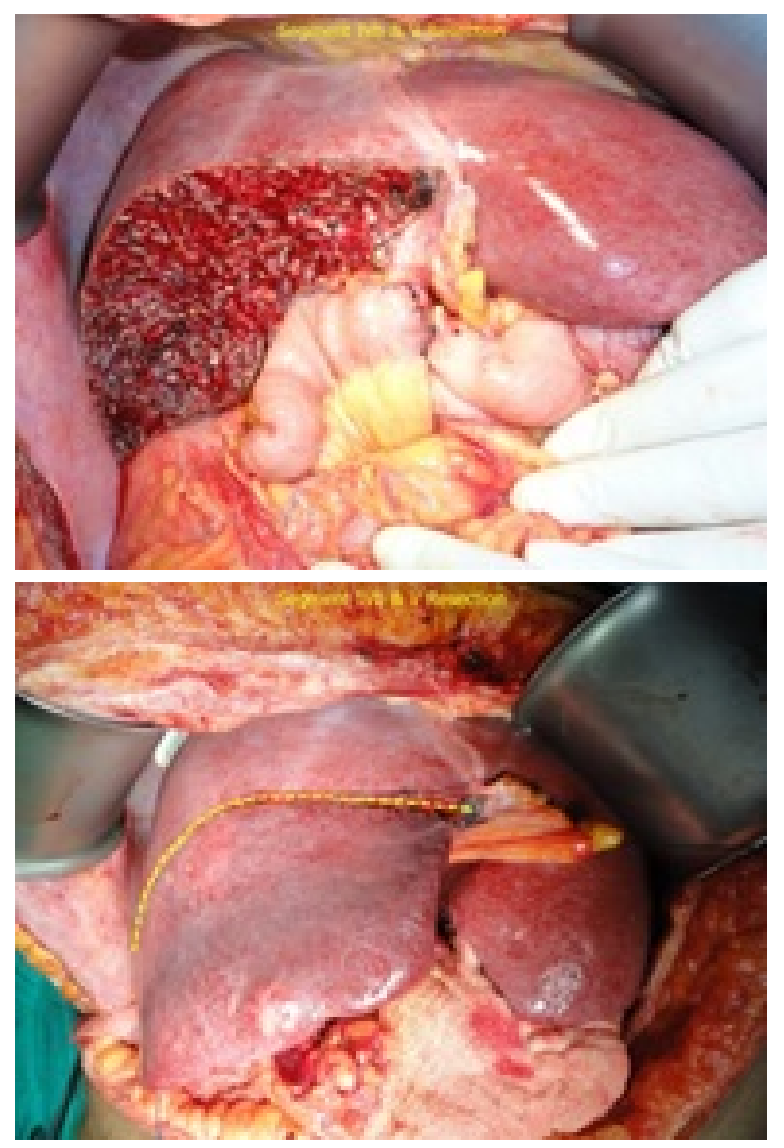

Fig-8: Showing intraoperative photographs of open extended cholecystectomy with wedge resection of the liver bed (segments IV and V) with roux-en-y hepaticojejunostomy. 

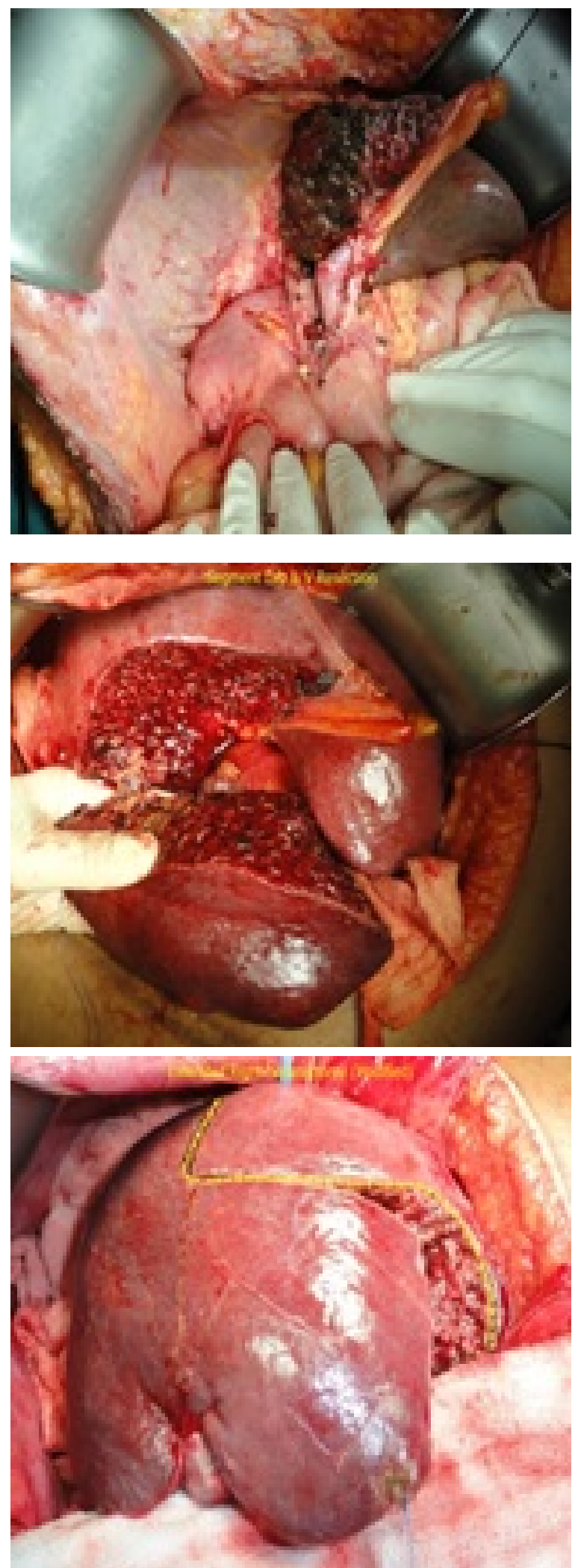

Fig-9- Showing intraoperative photographs of open extended cholecystectomy with right hepatic lobectomy with extension to segment
IV.

\section{Discussion}

Once gallbladder malignancy was regarded as uncommon, since the last 5 decades various reports have shown that it is not as rare as was previous. Probably many tumors were not diagnosed during the course of treatment. It contributes $5 \%$ of all malignancy detected during an autopsy. It ranks fifth most common of all alimentary tract malignancy.

Patients with gallbladder malignancy have an overall mean survival rate of 6 months, and the 5 years survival rate is $5 \%$ [9]. Aim of this study to find age and sex-related incidence with a comprehensive picture of the clinical aspect of the disease. This was a small study and may have limited epidemiological significance in certain aspects.

In this study, patients between 35 to 80 years of age are included. The highest incidence is noted in the 5th and 6th decades of life [1]. In another study by Nagata et al and de-Aretxabala et al found the highest incidence in the 6th decade of life [10] and Jones and Maibenco et al between ages 70 and 75 years $[11,12]$.

In this study, the youngest patient with gallbladder malignancy reported was 35 years old female while in other study conducted by Tanga and Ewing found the youngest patient was of 43 years [13], Maria et al at 41 years [14], while Petcher, found Carcinoma gallbladder in an 11-year-old Navajo girl.

Overall, carcinoma of the gall bladder was seen in females (74\%) than in males (26\%) with female to male ratio is $2.84: 1$. Our result is, nearly similar to that of other studies, in one study which is $3: 1$ [15] and 1.5:1 in another study [16]. In the present study, pain in the right hypochondrium was the commonest presenting symptom which is similar to the finding of Huber et al [15].

In the present study, among 100 patients of carcinoma gallbladder 78 patients (78\%) have cholelithiasis, in one study, by Cunningham et al found cholelithiasis in $48.2 \%$ of patients of carcinoma of the gallbladder [17]. It was found Jaundice in 30 patients (30\%). The study of Nagata et al he found jaundice in $35 \%$ of patients [10].

In biochemical investigations, Serum alanine aminotransferase was elevated in 76 patients $(76 \%)$, Serum Alkaline Phosphatase was raised in 
46 patients (46\%) and the Prothrombin time was prolonged in 35 patients (35\%). Raised levels of liver enzymes correlate with the severity of jaundice and degree of biliary tract obstruction. In the present study, USG findings were gallstones in 74 patients $(74 \%)$, Soft tissue shadow was detected in 70 patients $(70 \%)$; liver metastasis in 56 patients $(56 \%)$, dilated biliary channels in 28 patients $(28 \%)$.

In other studies, solid mass detected on USG in $50.84 \%$ cases of gallbladder carcinoma, gallbladder wall thickening in $44.06 \%$, and intra luminal polypoid mass in $5.08 \%$ cases, with an overall positive finding detected in $100 \%$ patients [18]. In one study Cubertaford et al found the USG sensitivity of about $64 \%$ in detecting gallbladder cancer [19], while other studies diagnostic accuracy of USG in detecting carcinoma of gallbladder is $>80 \%[20]$.

CECT abdomen was done in all patients Findings was Gallbladder mass found in all cases $(100 \%)$, liver metastases in $80(80 \%)$, gall stone 70 patients $(70 \%)$, lymphadenopathy in 40 cases $(40 \%)$.In another study, Araki et al showed a $60 \%$ sensitivity of gallbladder carcinoma in CT scan [21].

This variation is seen maybe because USG confirmed cancer patients were selectively sent for a CT scan. It was found that most of the patients presented with advanced disease, curative resection done in 16 patients (16\%). Among them, 3 patients ( $3 \%)$ were incidentally found to have CaGB one in open cholecystectomy and two in laparoscopic cholecystectomy, 15 patients underwent Open extended Radical cholecystectomy.

While in another study Hiromichi et al found $38 \%$ of patients underwent complete resection out of which $20.8 \%$ underwent simple cholecystectomy and $17.2 \%$ underwent radical cholecystectomy [22]. This variation may be because most of our patients presented late to us.

In the present study, 100 patient has biopsy-proven carcinoma $92 \%$ patients has adenocarcinoma, 6 patients $(6 \%)$ has squamous cell carcinoma and 2 patients $(2 \%)$ has papillary carcinoma, which was less or more similarity with the different studies (Table 6).

A similar study was done by Maria et al on 61 patients and was diagnostic in all the cases having adenocarcinoma [23] and Strauch et al found $82 \%$
Adenocarcinoma, $7 \%$ undifferentiated, $3 \%$ squamous cell carcinoma and remaining other rare varieties [24].

Table-6: Histopathological findings of biopsyproven cases $(\mathbf{n}=\mathbf{1 0 0})$.

\begin{tabular}{|l|l|l|l|}
\hline \multicolumn{1}{|c|}{ Type of carcinoma } & \multicolumn{2}{c|}{ Number of Patients } & \multicolumn{2}{c|}{ Percentage } \\
\cline { 1 - 3 } Adenocarcinoma & \multirow{2}{*}{25} & \multirow{2}{*}{$25 \%$} & \multirow{2}{*}{$\% 2 \%$} \\
\cline { 1 - 3 } Well-differentiated & 27 & $27 \%$ & \\
\hline Moderately differentiated & 40 & $40 \%$ & \\
\hline Poorly differentiated & 6 & $6 \%$ & \\
\hline Squamous cell carcinoma & 2 & $2 \%$ \\
\hline Papillary carcinoma & 2 & \\
\hline
\end{tabular}

Gallbladder cancer is a disease of elderly females with a high incidence of the 5th and 6th decade of life.

Mostly asymptomatic in early-stage and detected in advanced stages with symptoms mostly similar to benign diseases like pain in the right hypochondriac region, Jaundice, anorexia, weight loss, nausea, vomiting lump in the abdomen. Early CaGB may be detected by USG by the presence of $\mathrm{Gb}$ wall thickening, polyploid mass in GB lumen, however, differentiations are difficult from a benign disease like cholecystitis.

CECT accurately detects the GB cancer and extent of disease. USG / CT guided FNAC/biopsy reported to have $88 \%$ sensitivity in histopathological diagnosis. Biochemical investigations are not specific to have little diagnostic value. Tumor markers CEA and CA 19-9 occasionally raised and are nonspecific.

The majority of patients have advanced disease and very few patients are suitable for surgical resection. Even after surgical reaction due to the complexity of the hepato-biliary system and tumor spread during surgical handling. Adenocarcinoma was the most common histopathological type, squamous and papillary ware other rare types.

\section{Conclusion}

Gallbladder cancer is the most common malignancy of the biliary system and has a poor prognosis due to aggressive nature and not having a sensitive screening test to detect in an early stage. The diagnosis of gallbladder cancer remains low as it has indolent and nonspecific symptoms that mimic the benign biliary pathology. Even after advances made in the radiological field, early-stage detection of gallbladder cancer is challenging and the majority of 
Gallbladder malignancy detected in the advanced stage. As structures like liver and major vasculature present surrounding the gallbladder extensive hepatic resection are often required to eradicate the local disease.

\section{What does the study add to the existing knowledge}

Despite the many risk factors only $1 / 3$ rd CaGB detected pre-operatively and $<1 / 2$ of these Carcinomas are suitable for resection. Even among those suitable for resection, the complexity of the Porto biliary hepatic system, the morbidity/ mortality associated with liver resection, and the risk of tumor our spread during manipulation is high. Among the patients that underwent surgery recurrence rate is very high. Even though diagnosed at an early stage does not carry long term survival and prognosis. The future therefore to have improved outcomes in the management of carcinoma gallbladder should be directed towards the development of screening strategies with the relevant advanced molecular understanding that can detect disease in an early stage.

\section{Author's contribution}

All the authors, Dr. Mahim Koshariya, Dr. Tushar Suroshe, Dr. Sharon Alex, Dr. Gaurav Rajput, Dr. K M Guka Priyan, Dr. Kunal Vaidya, Resident, Dr. Shikha Shukla, Dr. Badri Patel, Dr. Megha Shalini, Dr. MC Songra have contributed significantly in the conducted of the study and in the preparation of the manuscript.

\section{Abbreviation}

LC- Laparoscopic cholecystectomy, OC- Open cholecystectomy, M:F - Male: Female, RUQ - Right upper quadrant, CCK-Cholecystokinin, CT Computed tomography, US- Ultrasound, MRCPMagnetic Resonance Cholangio pancreatography, PTC- percutaneous transhepatic cholangiography, CBD- Common Bile Duct, CaGB- Carcinoma gallbladder, GB - gallbladder, CHC- chronic cholecystitis, CCC- chronic calculus Cholecystitis

\section{Reference}

01. Varshney S, Butturini G, Gupta R. Incidental carcinoma of the gallbladder. Eur J Surg Oncol. 2002;28(1)4-10.

[Article] [Crossref]
02. Lillemoe KD. Tumors of the gallbladder, bile ducts, and ampulla, In- Feldman M, Friedman L, Brandt LJ, editors, Sleisenger and Fordtran's Gastrointestinal and Liver Diseases. Philadelphia, Pennsylvania- Saunders. 2006; pp; 1487-1502.

[Crossref]

03. Chijiiwa K, Tanaka M. Polypoid lesion of the gallbladder- indications of carcinoma and outcome after surgery for malignant polypoid lesions. Int Surg. 1994;79(2)106-109.

[Crossref]

04. Nagata E, Sakai K, Kinoshita H, Kobayashi Y. The relation between carcinoma of the gallbladder and an anomalous connection between the choledochus and the pancreatic duct. Ann Surg. 1985;202(2)182-190.

[Article] [Crossref]

05. Axelrod L, Munster AM, O'Brien TF. Typhoid cholecystitis and gallbladder carcinoma after interval of 67 years. JAMA. 1971;217(1)83.

[Article] [Crossref]

06. Roa I, de Aretxabala X, Araya JC, Roa J. Preneoplastic lesions in gallbladder cancer. J Surg Oncol. 2006;93(8)615-623.

[Article] [Crossref]

07. Aldouri AQ, Malik HZ, Waytt J, Khan S, Ranganathan K, Kummaraganti $S$, et al. The risk of gallbladder cancer from polyps in a large multiethnic series. Eur J Surg Oncol. 2008;35(1)48-51.

[Article] [Crossref]

08. Klamer TW, Max MH. Carcinoma of the gall bladder. Surg Gynecol Obstet. 1983;156(5)641645.

[Crossref]

09. Levy AD, Murakata LA, Rohrmann CA Jr. Gallbladder carcinoma- radiologic-pathologic correlation. Radiographics. 2001;21(2)295-314. [Article] [Crossref]

10. Nagata EI, Sakai K, Kinoshita HI, Kobayashi YA. The relation between carcinoma of the gallbladder and an anomalous connection between the choledochus and the pancreatic duct. Ann Surg. 1985;202(2)182-190. [Article] [Crossref]

11. Maibenco DC, Smith JL, Nava HR, Petrelli NJ, Douglass $\mathrm{HO}$. Carcinoma of the gallbladder. Cancer Invest. 1998;16(1)33-39.

[Crossref] 
12. Jones RS. Carcinoma of the gallbladder. Surg Oncol clin North Am. 1990;70(6)1419-1428. [Article] [Crossref]

13. Tanga MR, Ewing JB. Primary malignant turnours of the gall bladder, Report of 43 cases. Surg. $1970 ; 67(3) 418-426$.

[Crossref]

14. Perpetuo MD, Valdivieso M, Heilbrun LK, Nelson RS, Connor T, Bodey GP. Natural history study of gallbladder cancer- A review of 36 years experience at MD Anderson Hospital and Tumor Institute. Cancer. 1978;42(1)330-335.

[Article] [Crossref]

15. Huber DF, Martin EW, Coopcrman M. Cholecystectomy in elderly patients. Am J Surg. $1983 ; 146(6) 719-722$.

[Article] [Crossref]

16. Singh A, Bagga SP, Jindal VP, Singh K, Rato SS. Gall bladder diseases- An analytical report of 250 cases. J Indian Med Assoc. 1989;87(11)253-256.

[Crossref]

17. Houry S, Schlienger M, Huguier M, Lacaine F, Penne F, Laugier A. Gallbladder carcinoma- role of radiation therapy. $\mathrm{Br}$ J Surg. 1989;76(5)448450.

[Article] [Crossref]

18. Strauch GO. Primary carcinoma of the gallbladder, Presentation of seventy cases from the Rhode Island Hospital and a cumulative review of the last 10 years of the American Literature. Surg. 1960;47;368-383.

[Crossref]
19. Cunnigham CC, Zibari GB, Johnston LW. Primary carcinoma of the gallbladder- a review of our experience. J La State Med Soc. 2002,154(4)196-199.

[Crossref]

20. Nilsson P, Ekberg 0, Aspelin P, Sigurjonsson SV, Genell $S$. Ultrasonography in the diagnosis of gall bladder carcinoma. Forstscher Rontgenstr. 1989;150(2)171-175.

[Article] [Crossref]

21. Cubertaford P, Gainant A, Cucchiaro G. Surgical treatment of 724 carcinoma of the gall bladder - results of French Surgical Association. Ann surg. $1994 ; 219(3) 275-280$.

[Article] [Crossref]

22. Chijiwa K, Sumiyoshi K, Nakayama F. Impact of recent advances in hepatobiliary imaging techniques on the preoperative diagnosis of carcinoma of the gallbladder. World J Surg. 1991;15(3)332-337.

[Article] [Crossref]

23. Araki T, Hihara T, Karikomi M, Kachi K, Uchiyama G. Intraluminal papillary carcinoma of the gallbladder- prognostic value of computed tomography and sonography. Gastrointestinal radiol. $1988 ; 13(1) 261-265$.

[Article] [Crossref]

24. Ito $H$, Matros $E$, Brooks DC, Osteen RT, Zinner MJ, Swanson RS, et al. Treatment outcomes associated with surgery for gallbladder cancer- a 20-year experience. J Gastrointest Surg. 2004;8(2)183-190.

[Article] [Crossref] 